\title{
Using Environmentally Friendly Hydrogels to Alleviate the Negative Impact of Drought on Plant
}

\author{
Gehan H. Abd El-Aziz ${ }^{1}$, Ahmed S. Ibrahim², Ashraf H. Fahmy ${ }^{3}$ \\ ${ }^{1}$ Soils, Water and Environment Research Institute, Agricultural Research Center, Giza, Egypt \\ ${ }^{2}$ Cairo University-Plant Biotechnology Research Laboratories (CU-PBRL) Scientific Center of Excellence in Plant Biotechnology, \\ Plant Physiology Division, Department of Agricultural Botany, Faculty of Agriculture, Cairo University, Cairo, Egypt \\ ${ }^{3}$ Agriculture Genetic Engineering Research Institute, Agricultural Research Center, Giza, Egypt \\ Email: gehanhelmy@gmial.com
}

How to cite this paper: El-Aziz, G.H.A., Ibrahim, A.S. and Fahmy, A.H. (2022) Using Environmentally Friendly Hydrogels to Alleviate the Negative Impact of Drought on Plant. Open Journal of Applied Sciences, 12, 111-133.

https://doi.org/10.4236/ojapps.2022.121009

Received: November 18, 2021

Accepted: January 22, 2022

Published: January 25, 2022

Copyright $\odot 2022$ by author(s) and Scientific Research Publishing Inc. This work is licensed under the Creative Commons Attribution International License (CC BY 4.0).

http://creativecommons.org/licenses/by/4.0/

\begin{abstract}
The use of natural hydrogels in agriculture provides solutions to many problems without threatening the environment. This study aims to evaluate the potential impact of environmentally friendly hydrogels (pectin, starch and pectin + starch) in reducing the negative effects of drought stress on tomato yield and quality. Two different peels (orange peel and banana peel) are used to prepare environmentally friendly hydrogels. The water retention efficiency of hydrogels has been studied. Greenhouse experiment for tomato under drought stress was conducted during 2019. These hydrogels were used under several level of irrigation (100\%, $75 \%$, and $50 \%$ FC), soil without hydrogel was used as a control. The results showed that the eco-friendly hydrogels (starch, pectin, and pectin + starch) had capacity retention of water for a long time. The obtained data from the greenhouse experiment showed that the eco-friendly hydrogel showed a positive effect on retention of water and increase the soil moisture content compared to control. The highest increase was observed at pectin + starch treatment. This increase reached to 2.8-, 2.4and 2.0 -fold for $100 \%, 75 \%$ and $50 \%$ FC compared to the control. Ecofriendly hydrogel application under different drought conditions led to improve yield and quality of tomato fruits. Moreover, conversion of agricultural wastes to hydrogels and the use of these eco-friendly materials instead of synthetic hydrogels are necessary to utilize the limited natural resources and decrease the harmful impact of agricultural wastes on the environment and pave the way for the transition to a sustainable agriculture system.
\end{abstract}

\section{Keywords}

Eco-Friendly Hydrogel, Pectin, Starch, Tomato, Soil, Drought 


\section{Introduction}

Conversion of agricultural wastes to hydrogels and the use of these eco-friendly materials instead of synthetic hydrogels are necessary to utilize the limited natural resources and decrease the harmful impact of agricultural wastes on the environment and pave the way for the transition to a sustainable agriculture system. The use of natural hydrogels in agriculture has provided solutions to the problems of the present-day agriculture which is to maximize land and water productivity without threatening the environment and the natural resources. Several countries have not sufficient water resources to face their actual environmental, urban and agricultural requirements. As a result of water resource crisis, water-saving agriculture is necessary for sustainable development. Moreover, drought is portending to become increasingly severe due to climate change [1]. One of the new methods used for managing water in soil is the use of natural superabsorbent hydrogel as a storage tank to prevent water waste and increase irrigation efficiency [2]. Synthetic hydrophilic polymers (hydrogels) are a particular class of gels, produced by chemical stabilization of hydrophilic polymers in a tri dimensional network. Hydrogels are characterized by the ability to absorb and retain quantities of liquids (swelling) much greater, in terms of weight, than the initial weight of the material [3]. Superabsorbent hydrogel has widely used for agricultural purposes based on idea to use the swelling and water release properties to improve water availability for plants. Different possible agricultural applications of hydrogels have been defined by [4]. Hydrogels have been successfully used as soil improvement to increase the water holding capacity and nutrient retention of sandy soils, with a possible lowering of irrigation frequency [5]. These superabsorbent hydrogel polymers are applied in the soil to make a water supply, near the rhizosphere zone and advantage agriculture [6]. Hydrogels found applications as slow-release fertilizers and pesticides [7] and [8]. Most of the synthetic hydrogels on the market are acrylate-based products, thus not biodegradable and regarded as potential pollutants for the soil. As a result of increased attention to environmental protection issues, biodegradable natural hydrogel is of great interest for application in agriculture [9]. Hence, the development of multi-component Superabsorbents derived from natural polymer and eco-friendly additives becomes the subject of great interest due to their unique commercial and environmental advantages [10]. Recently, a series of new Superabsorbents characterised by eco-friendliness and biodegradability made from some natural materials such as starch [11] and [12], cellulose [13], chitosan [14] [15]), guar gum [16] and gelatin [17] have been utilized for fabricating multi-component Superabsorbents.

Fruit peels are the major by-products obtained through the processing of different fruit. This peel is not being used for any other application and is mostly dumped as solid waste at large expense. So, it is necessary to find applications for this peel as it can contribute to real environmental problems [18]. In Egypt banana fruits are considered the most popular fruits. The total cultivated areas 
reach 5500 feddans which produce about 1,100,000 tons of banana fruits with an average of 28.4 thousand tons/feddan. Green banana flesh and peel contain approximate $60 \%$ and $30 \%$ starch content (from dry mass), respectively indicating that they are an important starch resource [19].

Starch is one of the main reserve compounds in plants and is abundant in cereal grains, legumes, roots, and fruits. It is a homopolysaccharide consisting of chains of amylose and amylopectin. Amylose is constituted of glucose units connected by $\alpha$ - $(1,4)$ bonds, forming a linear chain, while amylopectin forms branched structures between the glucose units by means of $\alpha-(1,4)$ and $\alpha-(1,6)$ bonds [20]. In Egypt the annual production of oranges is estimated at 750 tons. The peel of oranges is traditionally not used at industrial scales unless small amount is used for jam processing and orange oil production [21]. As orange waste, orange peel has high levels of pectin $(25 \%-35 \%)$ and can be used as raw material for pectin extraction [22] and [23].

Pectin is a naturally occurring biopolymer that is finding increasing applications in the biotechnology industry [24]. It is a family of polysaccharides present in the cell walls of higher plants. Their structures consist of D-galacturonic acid units connected by $\alpha$ - $(1,4)$ bonds, forming a linear polysaccharide interrupted by highly branched regions [25]. Tomato is one of the most widely grown vegetables in the world. Most commercial tomato cultivars are drought sensitive at all stages of plant development, with seed germination and early seedling growth being the most sensitive stages [26].

The objectives of this study were to use fruit peels (orange and banana peels) for producing eco-friendly hydrogels and study the use of them for: 1) Mitigating the negative effects of drought stress on the yield and quality of tomato fruits. 2) Increasing of plant water use efficiency. 3) Improving the control-release of the herbicide Dicamba and preventing the pollution risk.

\section{Materials and Methods}

\subsection{Preparation of Pectin Hydrogel}

Pectin was prepared from orange peels (Figure 1(a)) (50 g of orange peel was added to citric acid solution (citric acid was added to the distilled water until the $\mathrm{pH}$ become one, the solution was heated at $80^{\circ} \mathrm{C}$ for 10 minutes. Solution was filtered after cooling. Ethanol was added to precipitate of pectin. The solution is filtered using fine filter cloth to separate jelly pectin which is dried at $50^{\circ} \mathrm{C}$ for two hours [27].

\subsection{Preparation of Banana Peel Starch}

Starch was prepared from banana peels (Figure 1(b)) according to method [28]. Banana peels were weighed and cleansed, cut into tiny pieces, dried and then was homogenized with sodium metabisulphite $0.3 \%$ at a proportion of banana peel: metabisulphite $(1: 2, \mathrm{w} / \mathrm{v})$. The solution was filtered, compressed using a cotton cloth filter. Filtrate (starch sediment) was maintained for $24 \mathrm{~h}$. The starch 


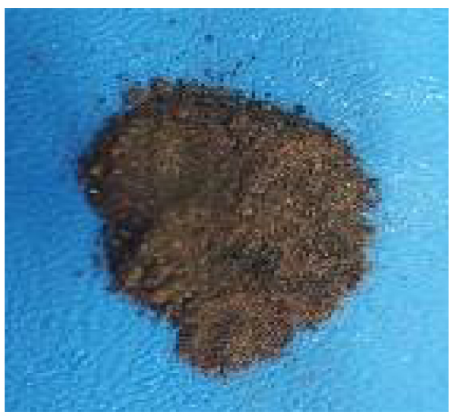

(a)

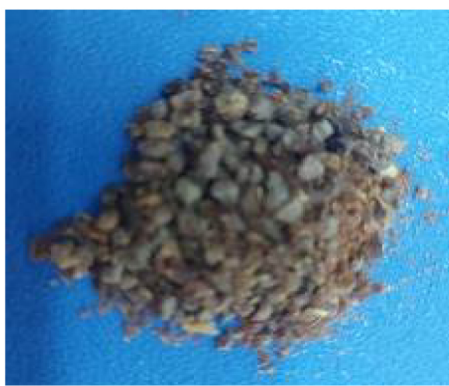

(b)

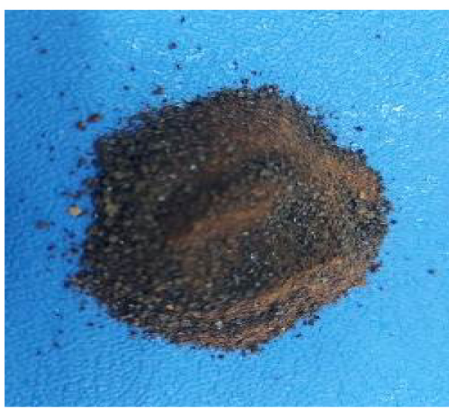

(c)

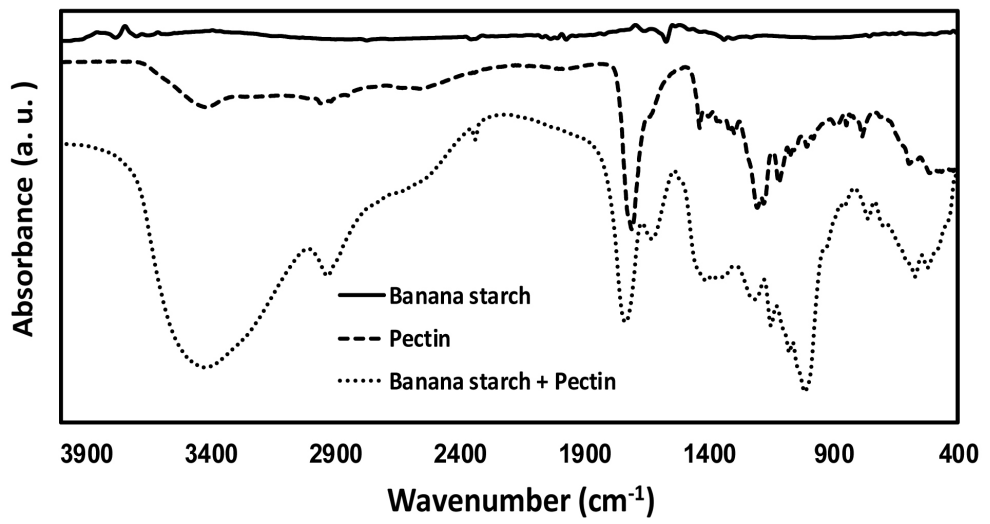

(d)

Figure 1. (a) Pectin hydrogel; (b) Banana peels starch; (c) Pectin + starch polymer; (d) FT-IR spectra of different hydrogels.

was collected and dried in at $60^{\circ} \mathrm{C}$ for $24 \mathrm{~h}$. The dried starch was grounded and screened through a 24 -mesh sieve. 


\subsection{Preparation of Pectin + Starch Cross-Linking}

Cross-linked with sodium trimetaphosphate of polymers was performed by the method described by [29], Pectin solution (2\% w/v) was prepared by mixing of $10 \mathrm{~g}$ pectin over night in $500 \mathrm{ml}$ aqueous solution. Banana starch gelatin (10 gm) was added to pectin solution (1:1) under high speed $5000 \mathrm{rpm}$ for $20 \mathrm{~min}$ then the solution was dried Figure 1(c). The structure of the all-hydrogel samples were assured by IR spectra.

\subsection{Measurement of Water Absorbency of Eco-Friendly Hydrogel}

Measurements of equilibrium water absorbency were performed at room temperature according to a traditional filtration method [30] series of small tea bag containing an accurate dry weight of each natural polymer samples (0.1 gm) were immersed in water, at room temperature. Swollen samples were weighted at different time interval up to it reached a fixed weight. The Swollen samples separated from water at different time by filtering and hung up for $15 \mathrm{~min}$. until no liquid was dropped off from the sample. The water absorbency, $Q$ of sample was calculated according to following equation;

$$
Q=\left[\left(A_{2}-A_{1}\right) / A_{1}\right] \times 100
$$

where, $A_{1}$ and $A_{2}$ are the weight of dry sample and swollen sample, respectively. $Q$ was calculated as grams of water per gram dry hydrogel.

\subsection{Determination of Polymer Water Retention Efficiency}

A pot with holes used to be supplied with $2 \mathrm{~kg}$ of soil (sandy loam). $4 \mathrm{~g}$ of eco-friendly polymer (starch, pectin, and pectin + starch) was once inserted and blended then weight of pot used to be listed $\left(R_{i}\right)$. All the pots had been irrigated unto saturation case at three hours. Next 1 hour from saturated state (3 hours), the weight of pot was listed at zero time $\left(R_{0}\right)$. All the pots were weighted after different times $2,4,6,8,10,12$ and 14 days $\left(R_{t}\right)$. Then using the following formula, we calculated the water retention percent according [30].

$$
R \%=1-\left[\left(R_{0}-R_{t}\right) /\left(R_{0}-R_{i}\right)\right] \times 100
$$

where, $R \%=$ percent water retain,

$R_{t}=$ weight at different time,

$R_{i}=$ initial weight,

$R_{0}=$ zero time.

\subsection{Eco-Friendly Hydrogel Retention Rate for Herbicide Dicamba}

To determine herbicide retention by each hydrogel, $120 \mathrm{ml}$ of dicamba (1000 $\mathrm{ppm}$ ) was applied to plastic pots filled with $2 \mathrm{Kg}$ of soil (sandy loam) amended with 4 gm of each natural polymer (pectin, starch, pectin + starch) separately. One liter of distilled water was then applied to the pots. Dicamba concentration was determined after different times $(2,7,12,17,22,27,32,37,42,47,52$ and 57 days) in the soil samples according to method of [31]. 


\subsection{Greenhouse Experiment}

The experiment was conducted at Agricultural Research Center; Giza, Egypt, Seedlings were transplanted on April $7^{\text {th }}$, during the growth season (2019), to study the effect of eco-friendly hydrogel (starch, pectin, and pectin + starch) to reduce negative effects of drought stress on tomato plants. Two seedlings of tomato (Lycopersicon esculentum L.) cultivar (Super Strain B) were planted in each plastic pot with five replicates for each treatment, each pot contained $10 \mathrm{~kg}$ sandy loamy soil. Hydrogel was added to soil at the rate of $2 \mathrm{~g} / \mathrm{Kg}$ of soil [32]. All treatments were irrigated at $100 \%, 75 \%$ and $50 \%$ of field capacity, respectively. For these treatments $(100 \%, 75 \%$ and $50 \%$ field capacity) soil water content (SWC) were $15.4 \%, 11.5 \%$ and $7.7 \%$, respectively. Soil water content was calculated according to (Coombs et al., 1987) using the following formula:

Soil water content; SWC $\%=[(\mathrm{FW}-\mathrm{DW}) / \mathrm{DW}] \times 100$

where (FW) was the fresh weight of a portion of the soil from the internal area of each pot and (DW) was the dry weight of the soil portion after oven drying at $85^{\circ} \mathrm{C}$ for 4 days. The experimental layout was a split-split plot design based on randomized complete blocks. Soil characteristics are presented in Table 1. Soil

Table 1. Some physical and chemical properties of the soil used.

\begin{tabular}{|c|c|}
\hline Physical & Value \\
\hline Coarse sand (\%) & 35.5 \\
\hline Fine sand (\%) & 39 \\
\hline Silt (\%) & 15.3 \\
\hline Clay (\%) & 10.2 \\
\hline Texture soil & Sandy loam \\
\hline \multicolumn{2}{|l|}{ Chemical } \\
\hline $\mathrm{pH}$ (1:2.5, soil suspension) & 7.48 \\
\hline SP & 30 \\
\hline ECe dS $\cdot \mathrm{m}^{-1}$, soil paste & 1.84 \\
\hline \multicolumn{2}{|l|}{ Soluble cations (me/L) } \\
\hline $\mathrm{Ca}^{2+}$ & 7.5 \\
\hline $\mathrm{Mg}^{2+}$ & 3.9 \\
\hline $\mathrm{Mg}^{2+}$ & 5.3 \\
\hline $\mathrm{K}^{2+}$ & 1.7 \\
\hline \multicolumn{2}{|l|}{ Soluble anions (me/L) } \\
\hline $\mathrm{CO}_{3}^{2-}$ & - \\
\hline $\mathrm{HCO}_{3}^{-}$ & 4.6 \\
\hline $\mathrm{Cl}^{-}$ & 7.1 \\
\hline $\mathrm{SO}_{4}^{2-}$ & 6.7 \\
\hline
\end{tabular}


was fertilized with recommended dose of mineral fertilizers. Soil samples were periodically collected before subsequent irrigations (3 days) until the end of the trial for determination of soil water content. At the end experiment (14 ${ }^{\text {th }} \mathrm{Au}$ gust) plants were collected to estimate growth characters, and yield components and the biochemical changes in the yielded fruits. The experiment consisted of these treatments: T1, T2, T3: soil only as control (without hydrogel); T4, T5, T6: soil + pectin; T7, T8, T9: soil + starch; and T10, T11, T12: soil + pectin + starch.

\subsection{Analytical Methods}

Analysis of the soil was determined according to [33]. For plant analysis, total soluble solids were estimated in freshly fruit by using Erma hand refractrometer. The juice content was measured and expressed as percent of total weight of the fruits. The $\mathrm{pH}$ of tomato fruits juice was determined using digital $\mathrm{pH}$ meter. Total flavonoid was measured by the aluminum chloride colorimetric assay according to [34]. The total soluble sugars were determined using phenol-sulfuric acid method as described by [35]. Total chlorophyll and carotenoid content of the pigments extracted was determined by spectrophotometer, according to the described method by [36]. Lycopene content of fruit was extracted according to [37]. Vitamine C was determined according to the method of [38]. At the end of the growth season all plants were collected then number and weight of fruits per pot were recorded. The obtained data of fruit fresh weight per pot (yield) and total amounts of water used for irrigation per pot during the growth season were used to calculated water use efficiency (WUE) as this equation:

WUE $=$ Pot yield $(\mathrm{g}) /$ Total amount of water $(\mathrm{L})$ per pot.

\subsection{Statistical Analysis}

Data obtained were exposed to the proper statistical analysis of complete randomized design [39]. Experiments were carried out in three replicates. Means obtained were differentiated using Duncan's new multiple range test [40].

\section{Results and Discussion}

\subsection{FT-IR Spectra of Hydrogel}

The FT-IR spectra show in Figure 1(d). IR spectrum of banana starch reveal a peak at $992 \mathrm{~cm}^{-1}$ related to characteristic starch backbone, additionally, the peaks at 1574,1659 and $2325 \mathrm{~cm}^{-1}$ for $\mathrm{O}-\mathrm{H}$ bending, $\mathrm{C}-\mathrm{C}$ aromatic ring stretching and $\mathrm{C}-\mathrm{H}$ stretching, respectively. Furthermore, the pectin spectrum reveals $3421 \mathrm{~cm}^{-1}$ for the $\mathrm{O}-\mathrm{H}$ stretching and 2918, 1690, 1299, 1207, 1122, 764 $\mathrm{cm}^{-1}$ for $\mathrm{C}-\mathrm{H}$ stretch of alkanes, $\mathrm{C}=\mathrm{O}$ stretch for alkynes, $\mathrm{C}-\mathrm{O}$ stretch for esters or carboxylic acid, C-N stretch, $\mathrm{C}-\mathrm{Cl}$ stretch, respectively. For the pectin + starch mix, the spectrum had shown the main peaks of pectin and starch. Also, the characteristic peak of pectin at $1960 \mathrm{~cm}^{-1}$ shifted to $1730 \mathrm{~cm}^{-1}$ and for starch peak of $1574 \mathrm{~cm}^{-1}$ shifted to $1625 \mathrm{~cm}^{-1}$. The adsorbed water molecules become more boarders. 


\subsection{Swelling and Water Retention of Eco-Friendly Hydrogel}

Data in Figure 2 showed fast initial swelling of each natural polymer followed by a gradual decrease in the rate of absorption until reach the point of equilibrium. All hydrogel had a same approach in the rate of water absorption. Average rate of absorption of water by hydrogel after 10, 20, 30, 60, 90, 120, 150, 180 and 360 min revealed that water absorption increased in a time course manner. The maximum absorption of water by different hydrogel after 150 to $360 \mathrm{~min}$ reached was found to be 529, 361, and 261 times of its weight for pectin + starch, pectin, and starch, respectively.

Data in Figure 3 observed that the eco-friendly hydrogels (starch, pectin, and pectin + starch) had capacity retention of water for a long time. Water retention percent reached to $47.6 \%, 54.1 \%$ and $67.9 \%$, respectively at 4 days of irrigation, whereas reached to $25 \%, 30 \%$, and $38 \%$ at 6 days compared to control. This may be due to its high molecular weight materials that can absorb as much as several hundred times of its weight. The results are in agreement with the earlier findings of [41].

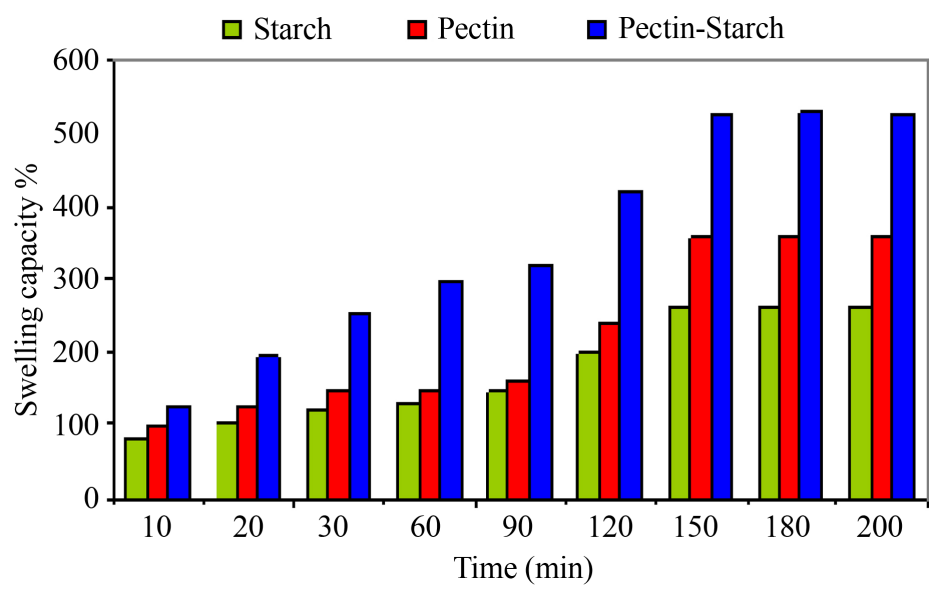

Figure 2. Swelling capacity of eco friendly hydrogel.

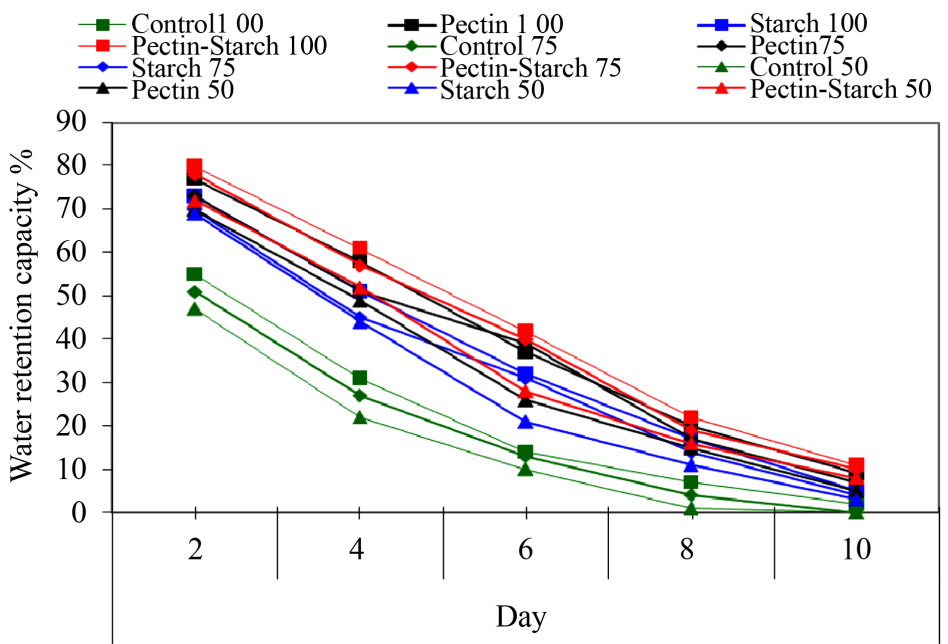

Figure 3. Water retention of soil with or without different eco-friendly hydrogel. 


\subsection{Hydrogel Retention Rate for Herbicides Dicamba}

The data showed the ability of all hydrogels to retain the herbicides Dicamba (Figure 4). The results showed that hydrogel had an excellent ability to retain the herbicide. The maximum loading of Dicamba herbicides was observed when used pectin + starch hydrogel. The retention of Dicamba by hydrogel was in following order pectin + starch $>$ pectin $>$ starch. Generally, hydrogel release the herbicides slowly in managed and sustained manner. The release $\%$ reached after 57 days to $1.7,3 \%$ and $2 \%$ for pectin, starch and pectin + starch, respectively. It is worth to mention that, very slightly change of herbicide concentration was observed in soil without any hydrogel until the end time (57 days). Hydrogels are important in creation of controlled release systems. They are capable of delivering active ingredient slowly and continuously for longer duration to a specified target at a desired rate. They minimize the impact of these harmful chemicals on the environment by reducing losses due to leaching, volatilization, and degradation and thereby maintaining biological efficacy of active ingredient [42]. Hydrogel have provided the slow-release profile to the pesticide and reactive functional groups reacts directly, or else bridging agents are also used to bind pesticide. The release will take place through diffusion or chemical cleavage of the bond between the hydrogel and herbicide [43].

\subsection{Influence of Eco-Friendly Hydrogel on Soil Moisture Content}

Data of soil moisture content at constant intervals are showed in Figure 5. Humidity of soil varies according to time periods. The obtained results showed a high soil moisture content using hydrogel compared to the control (soil without hydrogel). Data indicated that application of eco-friendly hydrogel to soil had a favorable influence to retain water and increase the humidity of soil compared to control. Data showed that all eco-friendly hydrogels under investigation (pectin, starch, and pectin + starch) strongly increased soil humidity. The largest increase was observed at pectin + starch treatment. This increase of pectin + starch

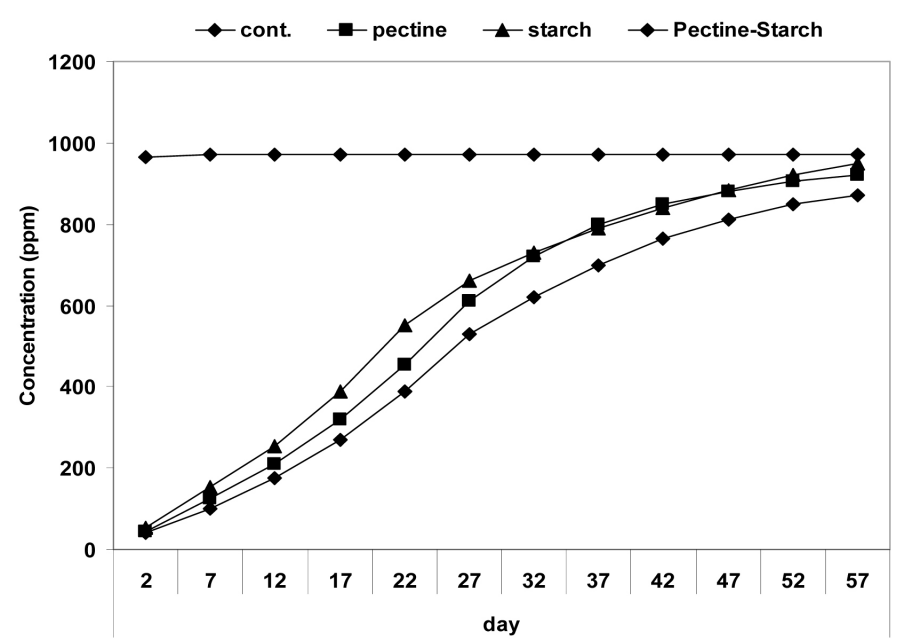

Figure 4. Release rete of dicamba herbicides from hydrogel. 


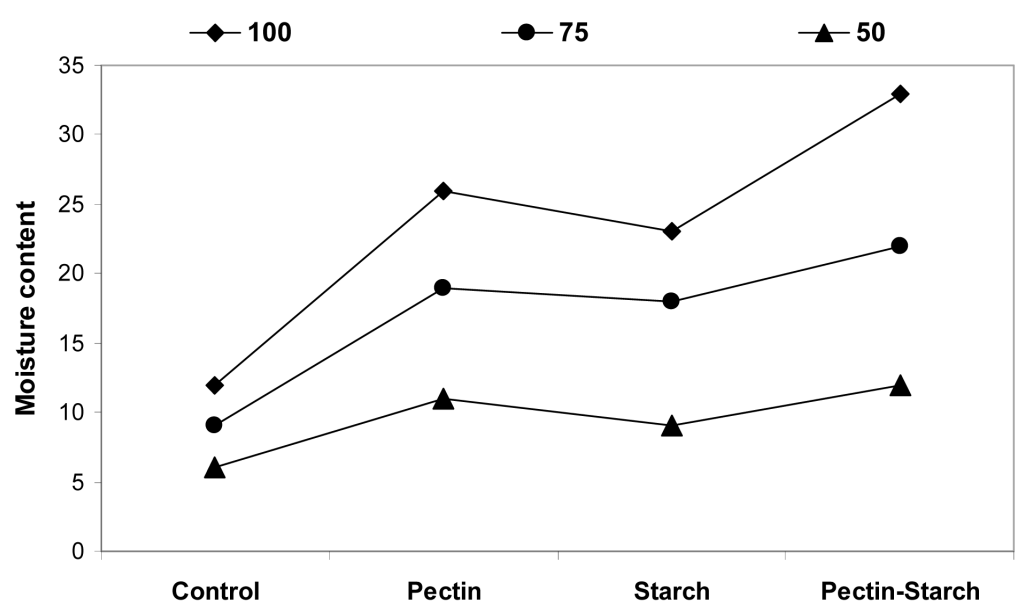

Figure 5. Influence of eco friendly hydrogel on soil moisture content.

treatment reached to $2.8-, 2.4-$ and 2.0 -fold for $100 \%, 75 \%$ and $50 \%$ FC respectively, compared to the control. Generally, eco-friendly hydrogels increase the humidity of soil compared to control. These increases were in order: pectin + starch $>$ pectin $>$ starch. The present results are in accordance with the recorded results of several workers [44] [45] [46] they mentioned that soils were treated by polymers had great potential in moisture retention.

\subsection{Influence of Drought and Eco-Friendly Hydrogel on Tomato Yield}

There was a significant effect of eco-friendly hydrogel on fruits weight and fruits number when grown under different levels of drought stress (Figure 6). Maximum of fruits weight and fruits number was found in pectin + starch treatment followed by pectin then starch treatment when tomato plants were irrigated at $100 \%$ of field capacity which was decreased by with irrigation at $75 \%$ of field capacity and with irrigation at $50 \%$ of field capacity compared to control. However, fruits weight was increased with hydrogel treatments; pectin + starch (1.57-fold), starch (1.36-fold) and with pectin (1.03-fold) under 100\% FC, compared to the control, pectin + starch (1.63-fold), starch (1.57-fold) and with pectin (1.16-fold) under $75 \%$ FC, compared to the control, pectin + starch (2.33-fold), starch (1.83-fold) and with pectin (1.50-fold) under 50\% FC, compared to the control. Natural hydrogel has the ability to absorb, hold and release water whenever require by the plants. Hence, this water is available for plants even at wilting point condition, these increases water use efficiency, decreases the infiltration losses, make water available at the root depth of plants, to increase the yield. Generally, hydrogel cause improvement in tomato growth by increasing their water use efficiency through increasing water-holding capacity in soil [47]. These data were agreed with [48] who reported that applying hydrogel had significant effect on plant height, dry weight of aerial organs, root dry weight and root length of plant. The results confirm the positive effects of hydrogels often reported on the plant growth promotion and the reduction of the 


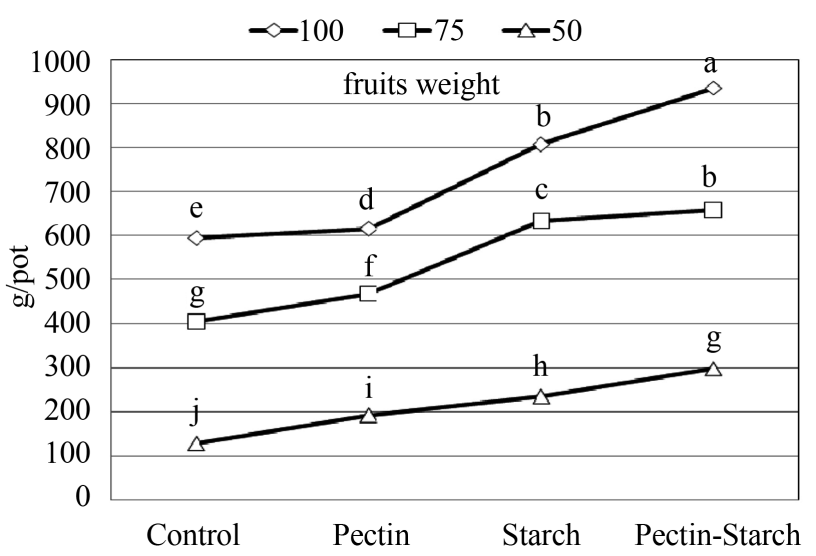

(a)

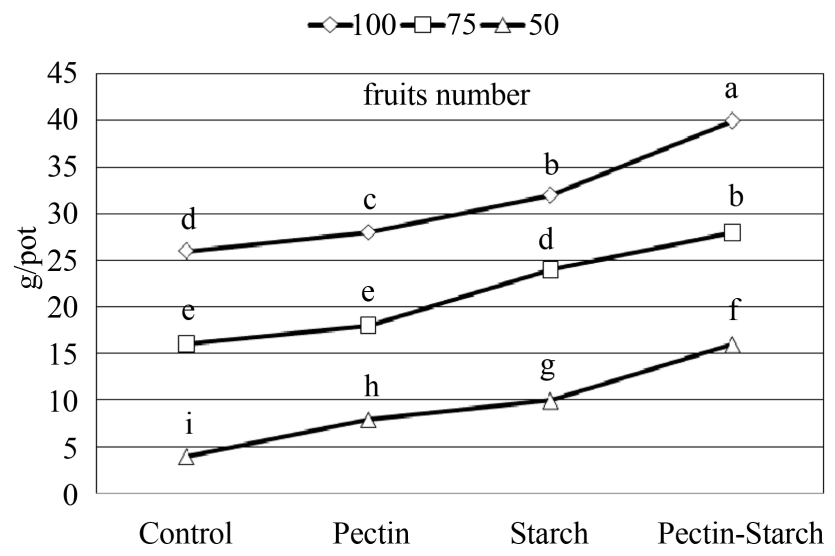

(b)

Figure 6. Influence of drought and Eco-friendly hydrogel on tomato growth.

detrimental effects of drought stress [49]. The improvement of vegetative growth with increasing irrigation level may be due to the proper balance of moisture in plant, which creates favorable conditions for nutrients uptake, photosynthesis and metabolites translocation, which ultimately accelerated the rate of vegetative growth [50]. Moreover, the reducing effect of the lowest level of irrigation water may be related to the negative effects of water defect stress on the activities of many enzymes leading to decrease in plant growth and dry matter accumulation. In conclusion polymers have the ability to absorb, hold and release water whenever require by the plants. By this water is available for plants even at wilting point condition, these increases water use efficiency by plants, decreases the infiltration losses, make water available at the root depth of plants, to increase the yield. Hydrogel polymers enhancement plant growth by increasing water holding capacity in soil and prolonged the time till reaching wilting point which increasing plants survival under drought stress [51]. In this respect, [52] mentioned that applying six quantities; $(0 \%, 0.2 \%, 0.4 \%, 0.6 \%, 0.8 \%, 1 \% \mathrm{w} / \mathrm{w})$ of the synthetic hydrophilic gel (Superab-A200 superabsorbent polymer) and four irrigation intervals $(2,3,4,5$ days) had significant positive effects under drought stress on number of leaves, number of flowers per plant, flower diameter, fresh 
and dry weight of flower, leaf area, leaf area ratio, number of stems, plant height, fresh and dry weight of roots and root/shoot ratio. The treatment of 2 days irrigation interval and $0.8 \%$ polymer resulted in the highest mean values in all traits excluding root/shoot ratio.

\subsection{Influence of Drought and Eco-Friendly Hydrogel on Photosynthetic Pigment}

Chlorophyll and carotenoids data of tomato leaves were showed in Figure 7 and Figure 8. The decrease in leaves chlorophyll values of the plants were recorded in plants that planted under drought stress cases in soil without eco-friendly hydro gel polymers. The lowest value of chlorophyll and carotenoids were observed

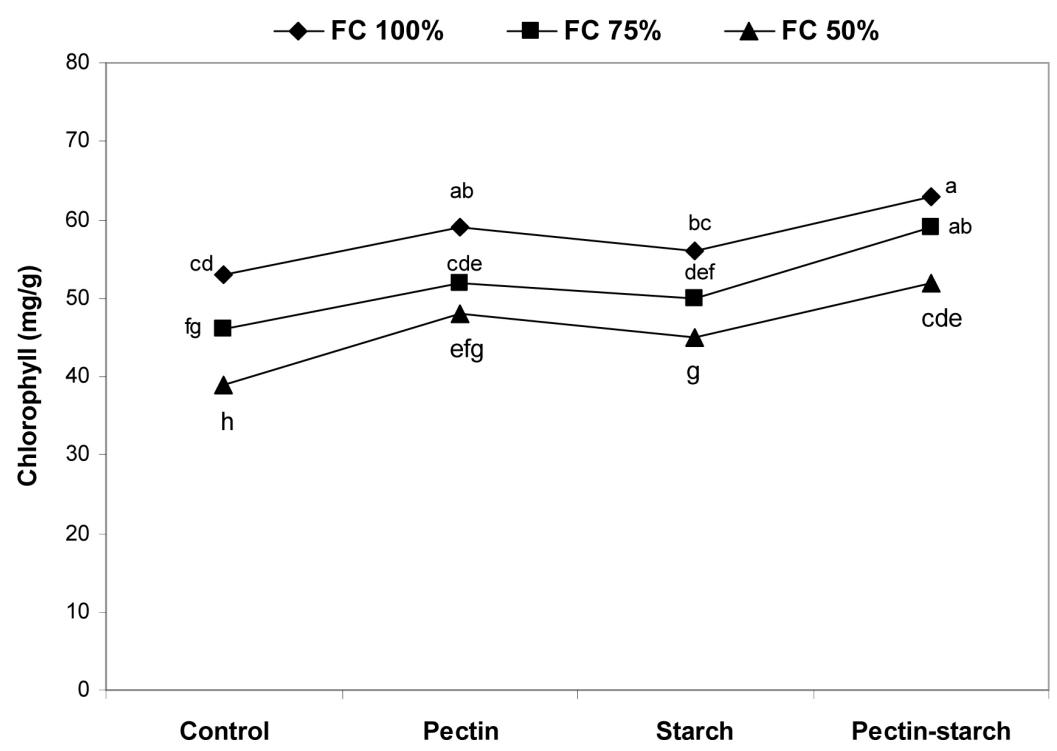

Figure 7. Influence of drought and eco friendly hydrogel on chlorophyll content.

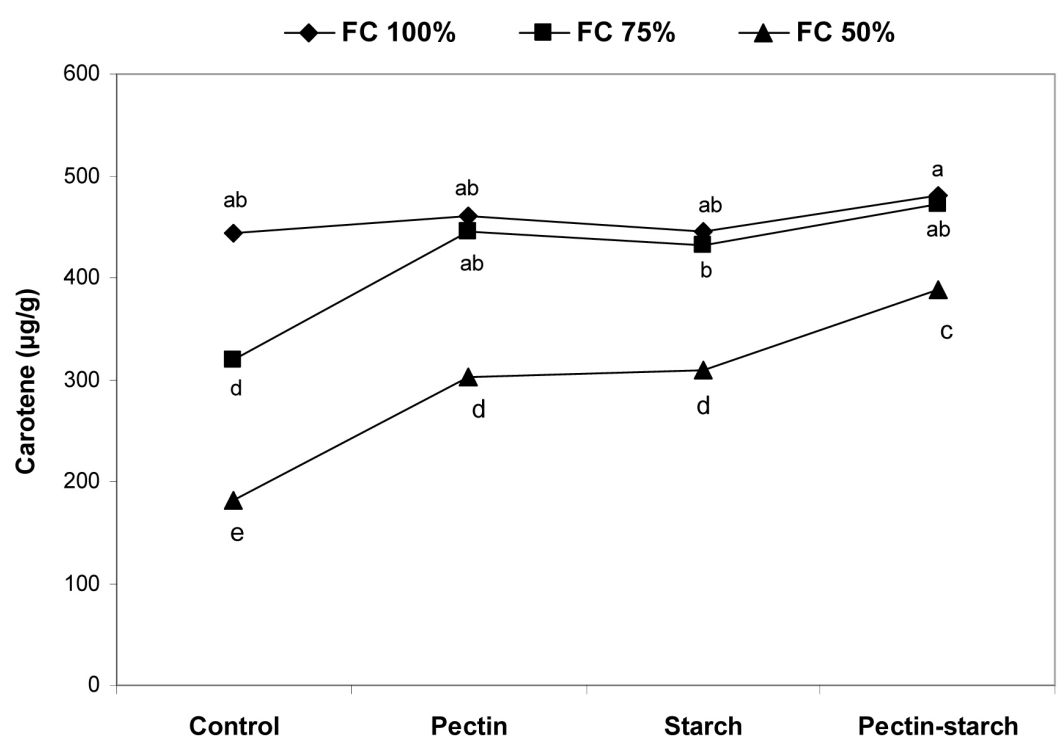

Figure 8. Influence of drought and eco friendly hydrogel on carotenoids content. 
at 50\% FC. On the contrary, data observed that apply of eco-friendly hydro gel polymers (pectin, starch, and pectin + starch) in soil under different levels from drought stress condition (100\%, 75\%, and 50\% FC) increased leaves chlorophyll and carotenoids values. For chlorophyll, the increase reached to $11 \%, 6 \%$ and $19 \%$ at $100 \% \mathrm{FC} ; 15 \%, 11 \%$, and $30 \%$ at $75 \% \mathrm{FC}$; and $23 \%, 15 \%$, and $33 \%$ at $50 \%$ FC, respectively compared to control without eco-friendly hydro gel polymers. Concerning the carotenoids, increase in carotene content reached to $4 \%, 1 \%$ and $8 \%$ at $100 \%$ FC; $39 \%, 35 \%$, and $48 \%$ at $75 \%$ FC; and $66 \%, 70 \%$, and $14 \%$ at $50 \%$ FC, respectively compared to control without eco-friendly hydro gel polymers. The performance of eco-friendly hydro gel polymers in increased total chlorophyll and carotene content were recorded in the following increasing order: starch $<$ pectin $<$ pectin + starch. This increase due to eco-friendly hydrgel polymer may be attributed to decrease in chlorophyll degradation or increased chlorophyll biosynthesis due to supply of sufficient amount of water and nutrients to the plant in water deficit condition. Generally, the major role of carotenoids through direct quenching of triplet chlorophyll prevents the generation of singlet oxygen and protects from oxidative damage. Chlorophyll and carotenoids absorb radiant energy, which is used for photosynthesis. In many observed cases chlorophyll content declines under drought stress conditions. Drought stress prevents photosynthesis of plant and cause an alteration in photosynthetic pigment and damage to the structures of the photosynthetic. In this regard [53] mentioned that the negative effects of drought stress on photosynthetic pigments may be due to the inhibition of chlorophyll biosynthesis or increase of its degradation by chlorophyllase enzyme. The ability to access to the water has an important role of leaves structure [54]. A positive effect was recorded for the use of eco-friendly hydro gel polymers to keep photosynthetic pigment content under drought stress. The present obtained results were in harmony with those obtained by [55] and [56] they mentioned that hydrogel had a positive effect of photosynthesis by gradually pumping water into the plant. Also, addition of hydrogel polymers had a positive effect on assimilation rate of $\mathrm{CO}_{2}$ and the water use efficiency of plants that grown under drought stress condition [57].

\subsection{Influence of Drought and Eco-Friendly Hydrogel on Total Soluble Sugars Content}

Data of total soluble sugars percent of tomato were showed in Figure 9. Maximum value of total sugars was observed in plants that grown under water stress conditions in soil without eco-friendly hydrogel. Total soluble sugars increase as the level of water shortage increases. The maximum increase was observed at $50 \%$ FC. The results showed no significant change in the total sugars of the plant that grown in soil with or without polymers at $100 \%$ FC. It is worth mentioning, data showed that use of all eco-friendly hydrogel (pectin, starch, pectin + starch) in soil with different water stress condition ( $75 \%$ and $50 \%$ FC) decreased total sugars content. The efficiencies of eco-friendly hydrogel to decreased total sugars were observed at pectin + starch treatment followed with pectin then starch. 


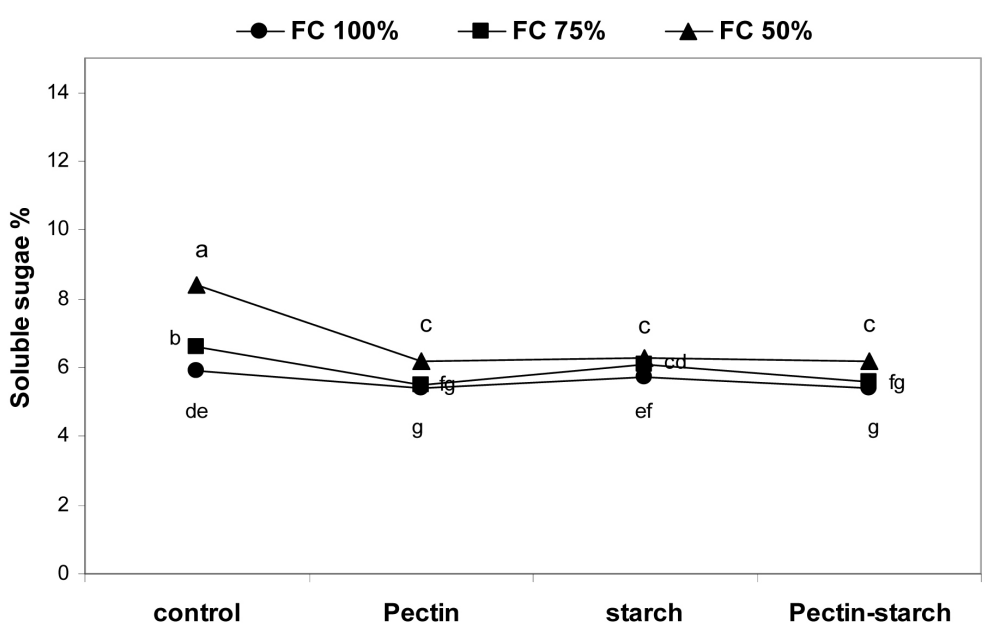

Figure 9. Effect of drought and eco friendly hydrogel polymers on soluble sugar.

Generally, water stress caused an increase in the concentration of total sugars in the plant. These results were agreed with [58]. Under water stress condition the breakdown of polysaccharides caused an accumulation of total sugars which help maintenance of growth of plant. Also, high levels of total sugars in leaves can be caused by high requirement for osmotic adjustment and membrane stabilization. Total soluble sugars content improves stress tolerance by protecting and stabilizing membranes and enzymes during stress conditions. These results were agreed with [59] they found the lowest amount in total sugars accumulation were achieved at $300 \mathrm{~kg} / \mathrm{ha}$ polymer compared with the control (without polymer).

\subsection{Influence of Drought and Eco-Friendly Hydrogel on Flavonoid Content}

Results of total flavonoid contents of tomato were showed in Figure 10. Total flavonoid content decreased depending on water stress levels. Minimum concentration of flavonoid was observed in plants that grown under water stress conditions. Total flavonoid contents decreased as the level of water stress increases. It is worth mentioning, data showed that use of all eco-friendly hydrogel (pectin, starch, and pectin + starch) in soil with different water stress condition. The efficiencies of eco-friendly hydrogel to increased flavonoid contents were observed especially at Pectin + starch treatment followed with pectin then starch. Generally, the acclimation of a plant to its growing environment is reflected in such physiological responses as accumulation of reactive oxygen and secondary metabolism [60]. The water stress had a significant effect on total flavonoids in tomato plant. These results are due to the fact that water is an important factor limiting the production and synthesis of total flavonoids in plant [61]. These results were consistent with previous findings that the content of total flavonoid was reduced in maize under drought stress [62]. The application of super absorbent polymer to growing media due to the reduced impact of water stress during the growing cycle can improve crop quality [63]. 


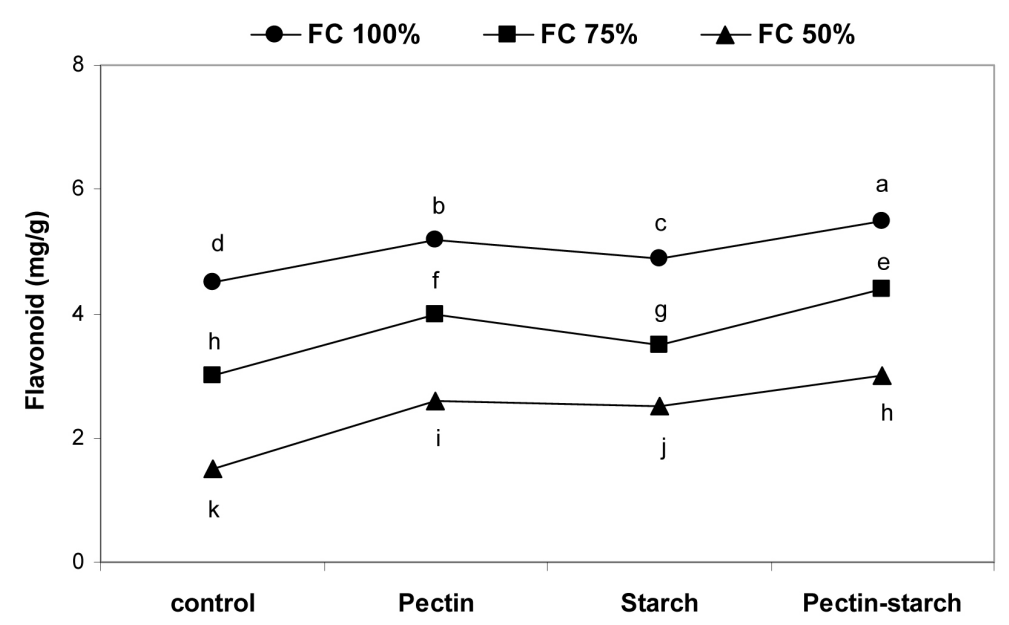

Figure 10. Influence of drought and eco friendly hydrogel on flavonoid content of tomato.

\subsection{Influence of Drought and Eco-Friendly Hydrogel on Fruits Quality}

Effect of drought and eco-friendly hydrogel on tomato fruit qualities were shown in Table 2. Ascorbic acid, total soluble solids (TSS), $\mathrm{pH}$, lycopene and juice \% increased by using of eco-friendly hydrogel. Minimum content of ascorbic acid was noticed in samples that exposed to drought stress conditions without eco-friendly hydrogel. Data observed that apply of eco-friendly hydrogel (pectin, starch, and pectin + starch) in soil with several level of drought condition $(100 \%, 75 \%$ and $50 \%$ FC) increased ascorbic acid content compared with soil without eco-friendly hydrogel. Increment reached to $9 \%, 5 \%$, and $15 \%$ for $100 \%$ FC; $11 \%, 7 \%$ and $16 \%$ for $75 \%$ FC; $19 \%, 17 \%$ and $22 \%$ for $50 \%$ FC. Reduce of ascorbic acid content by drought stress attributed to increase in activity of ascorbic acid oxidase enzyme that responsible for the destruction of ascorbic acid concentration in the tomato. The usage of eco-friendly hydrogel led to inhibition in the ascorbic acid oxidase enzyme and enhanced ascorbic acid formation in fruit due to supply of adequate quantity of water and nutrients to the plant in drought condition. An increase in ascorbic acid content was recorded in tomato due to the application of hydrophilic polymer [64]. Regarding the $\mathrm{pH}$ values, minimum values were recorded in samples were exposed to drought stress conditions without eco-friendly hydrogel. Data observed that use of all hydrogel (pectin, starch, and pectin + starch) in soil under several level of drought condition $(100 \%, 75 \%$ and $50 \% \mathrm{FC})$ enhanced $\mathrm{pH}$ value compared with control without hydrogel. Increase reached to $8 \%, 5 \%$, and $11 \%$ for $100 \%$ FC; $9 \%, 1 \%$ and $11 \%$ for $75 \% \mathrm{FC} ; 6 \%, 3 \%$ and $11 \%$ for $50 \% \mathrm{FC}$. Increase $\mathrm{pH}$ value in tomato due to use of hydrophilic polymer was noticed [64]. Lowering in the $\mathrm{pH}$ value of fruits under drought stress was because to change in the acid content [65]. Results showed that use of these natural polymers (pectin, starch, and pectin + starch) in soil with several level of drought condition (100\%, 75\% and $50 \%$ FC) increased TSS content compared to control without natural polymers Enhance. 
Table 2. Influence of drought and eco-friendly hydrogel on fruits quality.

\begin{tabular}{ccccccc}
\hline Treatment & $\begin{array}{c}\text { Field } \\
\text { capacity }\end{array}$ & $\mathrm{pH}$ & $\begin{array}{c}\text { TSS } \\
\%\end{array}$ & $\begin{array}{c}\text { Juice } \\
\%\end{array}$ & $\begin{array}{c}\text { Ascorbic acid } \\
(\mathrm{mg} / 100 \mathrm{~g})\end{array}$ & $\begin{array}{c}\text { Lycopene } \\
(\mathrm{mg} / 100 \mathrm{~g})\end{array}$ \\
\hline \multirow{3}{*}{ Control } & 100 & 3.81 & $3.31 \mathrm{~b}$ & 54 & $24.00 \mathrm{de}$ & $3.570 \mathrm{i}$ \\
& 75 & 3.70 & $3.12 \mathrm{e}$ & 50 & $22.80 \mathrm{f}$ & $3.213 \mathrm{j}$ \\
& 50 & 3.52 & $2.06 \mathrm{f}$ & 44 & $20.50 \mathrm{~g}$ & $2.940 \mathrm{k}$ \\
\hline \multirow{3}{*}{ Pectin } & 100 & 4.11 & $3.43 \mathrm{~d}$ & 59 & $26.20 \mathrm{~b}$ & $4.750 \mathrm{~b}$ \\
& 75 & 4.02 & $3.64 \mathrm{c}$ & 56 & $25.20 \mathrm{c}$ & $4.210 \mathrm{~d}$ \\
& 50 & 3.72 & $3.20 \mathrm{e}$ & 52 & $24.40 \mathrm{~d}$ & $3.843 \mathrm{~g}$ \\
\hline \multirow{3}{*}{ Starch } & 100 & 4.0 & $3.68 \mathrm{c}$ & 57 & $25.20 \mathrm{c}$ & $4.430 \mathrm{c}$ \\
& 75 & 3.75 & $3.48 \mathrm{~d}$ & 52 & $24.40 \mathrm{~d}$ & $4.040 \mathrm{f}$ \\
& 50 & 3.62 & $3.16 \mathrm{e}$ & 50 & $23.90 \mathrm{e}$ & $3.720 \mathrm{~h}$ \\
\hline \multirow{3}{*}{ Pectin + starch } & 75 & 4.21 & $3.94 \mathrm{a}$ & 64 & $27.50 \mathrm{a}$ & $5.020 \mathrm{a}$ \\
& 50 & 3.91 & $3.52 \mathrm{~d}$ & 54 & $24.90 \mathrm{C}$ & $4.120 \mathrm{E}$ \\
\hline
\end{tabular}

in TSS using hydrogel may be due to improve metabolic process and metabolic activities, led to the synthesis of more amounts of acids, metabolites and glucose. These metabolites share in the original composition of TSS [64]. Concerning the lycopene content, reduction in lycopene contents were noticed in plants that exposed to drought stress in soil without eco-friendly hydrogel. Lycopene content decreases as the level drought increases. The highest decrease was noticed at $50 \%$ FC. Data showed that apply of all hydrogel (pectin, starch, pectin + starch) in soil under several level of drought condition (100\%, 75\%, and $50 \% \mathrm{FC})$ enhanced lycopene content. Increase reached to $33 \%, 24 \%$, and $41 \%$ at $100 \%$ FC also $31 \%, 26 \%$ and $47 \%$ at $75 \% \mathrm{FC}$ also $31 \%, 27 \%$, and $40 \%$ at $50 \%$ FC, respectively compared with control that without hydrogel. lycopen is responsible for the red color of tomatoes [66]. Also, an increase in lycopen content was showed in tomato due to the application of hydrophilic polymer [64]. Also, the lowest percent for juice was observed in fruits that exposed to drought conditions in soil without hydrogel. Juice \% decreases by increase drought level. The highest decrease was noticed at 50\% FC. Data showed that use of all hydrogel (pectin, starch, pectin + starch $)$ in soil with different water stress condition $(100 \%, 75 \%$, and $50 \% \mathrm{FC}$ ) increased juice percent. Increase reached to $9 \%, 6 \%$, and $19 \%$ at $100 \%$ FC; $12 \%, 4 \%$, and $22 \%$ at $75 \%$ FC finely $18 \%, 14 \%$, and $23 \%$ at $50 \%$ FC, respectively compared with fruits without hydrogel at the same level irrigation. Similarly, [64] also reported an increase in juice content in tomato due to the application of hydrophilic polymer. [67] stated that applying hydrogel as a soil conditioner under water stress has positively affected on growth characters of potato plants; it increased nutrients uptake, plant water relations, total chlorophyll and increased nitrogen use efficiency as well as tuber yields and quality. 


\subsection{Water Use Efficiency of Tomato Plants}

Hydrogel can increase water use efficiency (WUE) which means the ratio of yield over crop water consumption through the strategy of reducing water loss in the soil by increasing water holding capacity of the soil depending on the properties of the hydrogel polymer to retain water shells around the molecules of the polymers. In conclusion polymers have the ability to absorb, hold and release water whenever require by the plants. Data in Table 3 showed water use efficiency of tomato as influenced by eco-friendly hydrogel under various irrigation levels. The differences in the values of water use efficiency were detected between treatments. The use of hydrogel resulted in reducing the amount of water used for tomato irrigation compared to the control treatment (without hydrogel). Water use efficiency of tomato under various levels of drought stress was increased as a result of using the hydrogel treatment in comparison with the control (without hydrogel). Thus, the efficiency of hydrogel treatments in increasing water use efficiency was in the following order: pectin $+\operatorname{starch}(242.37 \%)>$ starch $(209.34 \%)>$ pectin $(159.80 \%)$ for $100 \%$ FC, pectin + starch $(259.25 \%)>$ starch $(247.30 \%)>$ pectin $(182.53 \%)$ for $75 \%$ FC while pectin + starch $(360.16 \%)>$ starch $(283.05 \%)>$ pectin $(231.56 \%)$ for $50 \%$ FC. These results confirmed that hydrogel treatments had a positive influence on the productivity of tomato plants and consequently on the values of water use efficiency. Therefore, these natural eco-friendly hydrogels proved to be useful in reducing water loss and for improving the water use efficiency of tomato plant as well as sustaining the productivity of tomato under drought stress treatments ( $75 \%$ and $50 \%$ FC). The obtained results are in agreement with [68].

\subsection{Eco-Friendly Hydrogel and Save Water to Tomato Plants}

From the previous results and as shown in Table 3, the use of different hydrogels led to decrease the amount of water used to irrigate the tomato plants (Figure 11), however the yield of tomato plants was increased in comparison to the control treatments. Hence, the quantity of saving water was $19 \mathrm{~L} /$ pot for $100 \%$

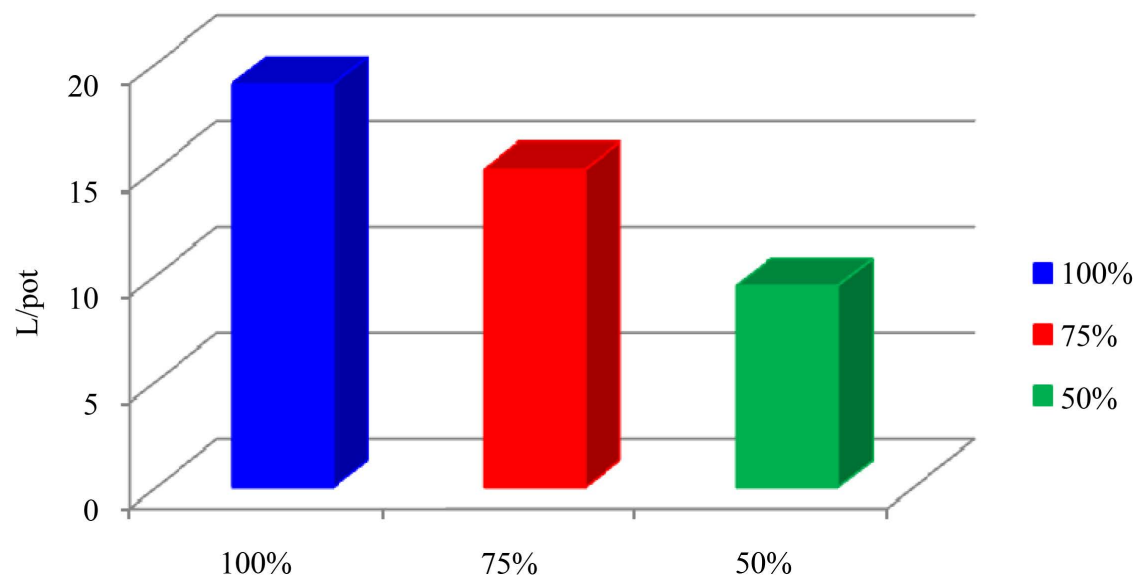

Figure 11. Eco friendly and save water to tomato plant at different irrigation. 
Table 3. Water use efficiency of tomato plants as influenced by Eco-friendly hydrogel under various irrigation levels.

\begin{tabular}{ccccc}
\hline \multirow{2}{*}{ Treatment } & $\begin{array}{c}\text { Field } \\
\text { capacity }\end{array}$ & $\begin{array}{c}\text { Yield } \\
(\mathrm{g} / \text { pot })\end{array}$ & $\begin{array}{c}\text { Water applied } \\
(\mathrm{L} / \text { pot })\end{array}$ & $\begin{array}{c}\text { WUE } \\
(\mathrm{g} / \mathrm{L})\end{array}$ \\
\hline \multirow{3}{*}{ Control } & 100 & 595.0 & 54.0 & 11.02 \\
& 75 & 403.7 & 41.0 & 9.85 \\
Pectin & 50 & 127.5 & 27.0 & 4.72 \\
\hline Starch & 100 & 616.3 & 35.0 & 17.61 \\
& 75 & 467.5 & 26.0 & 17.98 \\
& 50 & 191.3 & 17.5 & 10.93 \\
\hline & 100 & 807.5 & 35.0 & 23.07 \\
& 75 & 633.3 & 26.0 & 24.36 \\
& 50 & 233.8 & 17.5 & 13.36 \\
\hline & 100 & 935.0 & 35.0 & 26.71 \\
\hline & 75 & 658.8 & 26.0 & 25.34 \\
\hline & 50 & 297.5 & 17.5 & 17.00 \\
\hline
\end{tabular}

${ }^{\star}$ Water applied (L/pot) for tomato plants during the growth season.

FC while $15 \mathrm{~L} /$ pot for $75 \%$ and $9.5 \mathrm{~L} /$ pot for $50 \%$ FC during the growth season. These results indicate to the effective role of these natural eco-friendly hydrogels in reducing water loss in the soil by increasing water holding capacity of the soil and consequently providing the roots of plants with more amounts of available water than the control (soil without hydrogel). Therefore, the use of these natural eco-friendly hydrogels is a reliable amendment to increase water use efficiency by plants through reducing water loss in the soil and saving valuable amounts of water during the growth season.

\section{Conclusion}

Results of this study recommend the use of eco-friendly hydrogel as pectin, starch and pectin-starch for reducing the damaging action of water shortage on tomato growth and fruits quality without harmful effects on the environment. Natural hydrogel applications caused increase soil water retention 35\% and improve tomato growth and fruits quality under normal or drought conditions.

\section{Conflicts of Interest}

The authors declare no conflicts of interest regarding the publication of this paper.

\section{References}

[1] Gornall, J., Betts, R., Burke, E., Clark, R., Camp, J., Willett, K. and Wiltshire, A. (2010) Implications of Climate Change for Agricultural Productivity in the Early 
Twenty-First Century. Philosophical Transaction of the Royal Society B, 365, 2973 2989. https://doi.org/10.1098/rstb.2010.0158

[2] Khodadadi-Dehkordi, D. and Seyyedboveir, S. (2013) Evaluation of Super AB A 200 Superabsorbent on Water Use Efficiency and Yield Response Factor of SCKaroun701 Corn under Deficit Irrigation. Advances in Environmental Biology, 7, 46154622.

[3] Horie, K., Baròn, M., Fox, R., He, J., Hess, M., Kahovec, J., Kitayama, T., Kubisa, P., Marèchal, E. and Mormann, W. (2004) Definition of Terms Relating to Reactions of Polymers and to Functional Polymeric Materials (IUPAC Recommendations 2003). Pure and Applied Chemistry, 76, 889-906. https://doi.org/10.1351/pac200476040889

[4] Zohuriaan-Mehr, M.J. and Kabiri, K. (2008) Superabsorbent Polymer Materials: A Review. Iranian Polymer Journal, 17, 451-477.

[5] Abd El-Rehim, H.A., Hegazy, E.S.A. and Abd El-Mohdy, H.L. (2004) Radiation Synthesis of Hydrogels to Enhance Sandy Soils Water Retention and Increase Plant Performance. Journal of Applied Polymer Science, 93, 1360-1371. https://doi.org/10.1002/app.20571

[6] Han, Y.G., Yang, P.L., Luo, Y.P., Ren, S.M., Zhang. L.X. and Xu, L. (2010) Porosity Change Model for Watered Super Absorbent Polymer-Treated Soil. Environmental Earth Sciences, 61, 1197-1205. https://doi.org/10.1007/s12665-009-0443-4

[7] Teodorescu, M., Lungu, A. and Stanescu, P.O. (2009) Preparation and Properties of Novel Slow-Release NPK Agrochemical Formulations Based on Poly (Acrylic Acid) hydrogels and Liquid Fertilizers. Industrial \& Engineering Chemistry Research, 48, 6527-6534. https://doi.org/10.1021/ie900254b

[8] Rudzinski, W.E., Dave, A.M., Vaishnav, U.H., Kumbar, S.G., Kulkarni, A.R. and Aminabhavi, T.M. (2002) Hydrogels ascontrolled Release Devices Inagriculture. Designed Monomers and Polymers, 5, 39-65. https://doi.org/10.1163/156855502760151580

[9] Cannazza, G., Cataldo, A., De Benedetto, E., Demitri, C., Madaghiele, M. and Sannino, A. (2014) Experimental Assessment of the Use of a Novel Superabsorbent Polymer (SAP) for the Optimization of Water Consumption in Agricultural Irrigation Process. Water, 6, 2056-2069. https://doi.org/10.3390/w6072056

[10] Kurita, K. (2001) Controlled Functionalization of the Polysaccharide Chitin. Progress in Polymer Science, 26, 1921-1971. https://doi.org/10.1016/S0079-6700(01)00007-7

[11] Lanthong, P., Nuisin, R. and Kiatkamjornwong, S. (2006) Graft Copolymerization, Characterization, and Degradation of Cassava Starch-g-Acrylamide/Itaconic Acid Superabsorbents. Carbohydrate Polymers, 66, 229-245. https://doi.org/10.1016/j.carbpol.2006.03.006

[12] Li, A., Zhang, J.P. and Wang, A.Q. (2007) Utilization of Starch and Clay for the Preparation of Superabsorbent Composite. Bioresource Technology, 98, 327-332. https://doi.org/10.1016/j.biortech.2005.12.026

[13] Suo, A.L., Qian, J., Yao, Y. and Zhang, W.G. (2007) Synthesis and Properties of Carboxymethyl Cellulose-Graft-Poly (Acrylic Acid-co-Acrylamide) as a Novel Cellulose-Based Superabsorbent. Journal of Applied Polymer Science, 103, 1382-1388. https://doi.org/10.1002/app.23948

[14] Mahdavinia, G.R., Zohuriaan-Mehr, M.J. and Pourjavadi, A. (2004) Modified Chitosan III, Superabsorbency, Salt- and pH-Sensitivity of Smart Ampholytic hydrogels from Chitosan-g-PAN. Polymers for Advanced Technologies, 15, 173-180. https://doi.org/10.1002/pat.408 
[15] Zhang, J.P., Wang, Q. and Wang, A.Q. (2007) Synthesis and Characterization of Chitosan-g-Poly (Acrylic Acid)/Attapulgite Superabsorbent Composites. Carbohydrate Polymers, 68, 367-374. https://doi.org/10.1016/j.carbpol.2006.11.018

[16] Wang, W.B. and Wang, A.Q. (2009) Preparation, Characterization and Properties of Superabsorbent Nanocomposites Based on Natural Guar Gum and Modified Rectorite. Carbohydrate Polymers, 77, 891-897. https://doi.org/10.1016/j.carbpol.2009.03.012

[17] Pourjavadi, A. and Mahdavinia, G.R. (2006) Superabsorbency, pH-Sensitivity and Swelling Kinetics of Partially Hydrolyzed Chitosan-g-Poly (Acrylamide) Hydrogels. Turkish Journal of Chemistry, 30, 595-608.

[18] Zhang, P., Whistler, R.L.B.E., Miller, J.N. and Hamakerand, B.R. (2005) Banana Starch: Production, Physicochemical Properties and Digestibility-A Review. Carbohydrate Polymers, 59, 443-458. https://doi.org/10.1016/j.carbpol.2004.10.014

[19] Hernández-Carmona, F., Morales-Matos, Y., Lambis-Miranda, H. and Pasqualino, J. (2017) Starch Extraction Potential from Plantain Peel Wastes. Journal of Environmental Chemical Engineering, 5, 4980-4985. https://doi.org/10.1016/j.jece.2017.09.034

[20] Laycock, B.G. and Halley, P.J. (2014) Chapter 14. Starch Applications: State of Market and New Trends. In: Avérous, L. and Halley, P.J., Eds., Starch Polym, Elsevier, Amsterdam, 381-419. https://doi.org/10.1016/B978-0-444-53730-0.00026-9

[21] Masoud, M.R.M., Fatma, H. and Lobnaa, H. (2017) Utilization of Orange Wastes for Production of Value Added Products. Egyptian Journal of Agricultural, 95, 221-231. https://doi.org/10.21608/ejar.2017.146856

[22] Kohn, R. (2002) Binding Toxic Cations to Pectin, Its Oligomer Fragment and Plant Tissues. Carbohydrate Polymer, 2, 273-275. https://doi.org/10.1016/0144-8617(82)90030-3

[23] Nitin, G.K., Chirag, S., Swapnil, S. and Vishal, S. (2017) Extraction of Pectin from Orange Peel's and Its Applications: Review. International Journal of Innovative Research in Science, 6, 19452-19457.

[24] Tiwari, A.K. (2017) Extraction and Characterization of Pectin from Orange Peels. International Journal of Biotechnology and Biochemistry, 13, 39-47.

[25] Bayarri, M., Oulahal, N., Degraeve, P. and Gharsallaoui, A. (2014) Properties of Lysozyme/Low Methoxyl (LM) Pectin Complexes for Antimicrobial Edible Food Packaging. Journal of Food Engineering, 131, 18-25. https://doi.org/10.1016/j.jfoodeng.2014.01.013

[26] Foolad, M.R., Zhang, L.P. and Subbiah, P. (2003) Genetics of Drought Tolerance during Seed Germination in Tomato: Inheritance and QTL Mapping. Genome, 46, 536 -545. https://doi.org/10.1139/g03-035

[27] Pandharipande, S. and Harshal, M. (2012) Separation of Oil and Pectin from Orange Peel and Study of Effect of pH of Extracting Medium on the Yield of Pectin. Journal of Engineering Research and Studies, 3, 6-9.

[28] Hadisoewignyo, L., Foe, K. and Tjandrawinata, R.R. (2017) Isolation and Characterization of Agung Banana Peel Starch from East Java Indonesia. International Food Research Journal, 24, 1324-1330

[29] Cury, B.S.F., Klein, S.I. and Evangelista, R.C. (2008) Modeling a System of Phosphated Cross-Linked High Amylose for Controlled Drug Release. Part 1: Synthesis and Polymer Characterization. Reactive and Functional Polymers, 68, 1200-1206. https://doi.org/10.1016/j.reactfunctpolym.2008.04.003 
[30] Irani, M., Ismail, H. and Ahmad, Z. (2014) Hydrogel Composites Based on Linear Low-Density Polyethylene-g-Poly (Acrylic Acid)/Kaolin or Halloysite Nanotubes. Journal of Applied Polymer Science, 131, Article ID: 40101. https://doi.org/10.1002/app.40101

[31] Krzyszowska, A.J. and Vance, G.F. (1994) Solid-Phase Extraction of Dicamba and Picloram from Water and Soil Samples for HPLC Analysis. Journal of Agricultural and Food Chemistry, 42, 1693-1696. https://doi.org/10.1021/jf00044a020

[32] Aloys, H., Baguma Orikiriza, L.J., Osoto Esegu, J.F., Obua, J., Kabasa, J.D. and Hüttermann, A. (2010) Effects of Hydrogel Amendment to Different Soils on Plant Available Water and Survival of Trees under Drought Conditions. CLEAN-Soil, Air, Water, 38, 328-335. https://doi.org/10.1002/clen.200900245

[33] Page, A.L., Miller, R.H. and Keeney, D.R. (1982) Methods of Soil Analysis. II: Chemical and Microbiological Properties. 2nd Edition, Amer Society of Agronomy, Academic Press, Madison.

[34] Wei, L.H. and Intan, S.I. (2012) Antioxidant Activity, Total Phenolics and Total Flavonoids of Syzygiumpolyanthum (Wight) Walp Leaves. International Journal of Medicinal and Aromatic Plants, 2, 219-228.

[35] Dubois, M., Cilles, K.A., Hamilton, J.K., Rober, P.A. and Smith, F. (1956) Colorimetric Method for Determination of Sugars Related Substances. Analytical Chemistry, 28, 350-365. https://doi.org/10.1021/ac60111a017

[36] Sims, D.A. and Gamon, J.A. (2002) Relationships between Leaf Pigment Content and Spectral Reflectance across a Wide Range of Species, Leaf Structures and Developmental Stages. Remote Sensing of Environment, 81, 337-354.

https://doi.org/10.1016/S0034-4257(02)00010-X

[37] Fish, W.W., Perkins-Veazie, P. and Collins, J.K. (2002) A Quantitative Assay for Lycopene That Utilizes Reduced Volumes of Organic Solvents. Journal of Food Composition and Analysis, 15, 309-317. https://doi.org/10.1006/jfca.2002.1069

[38] Hewitt, E.J. and Dickes, G.J. (1961) Spectrophotometric Measurements on Ascorbic Acid and Their Use for the Estimation of Ascorbic Acid and Dehydroascorbic Acid in Plant Tissues. Biochemical Journal, 78, 384-391.

https://doi.org/10.1042/bj0780384

[39] Snedecor, G.W. and Cochran, W.G. (1969) Statistical Methods. 6th Edition, The Iowa State University, Ames.

[40] Duncan, D.B. (1955) Multiple Range and Multiple F tests. Biometrics, 11, 1-42.

[41] Vijayalakshmi, M., Nemichandrappa, K., Sreenivas, R. and Ayyanagowdar, M.S. (2012) Effect of Polymers on Moisture Retention and Soil Water Holding Capacity. Karnataka Journal of Agricultural Sciences, 25, 469-471.

[42] Campos, E.V.R., de Oliveira, J.L. and Fraceto, L.F. (2014) Applications of Controlled Release Systems for Fungicides, Herbicides, Acaricides, Nutrients, and Plant Growth Hormones: A Review. Advanced Science, Engineering and Medicine, 6, 373-387. https://doi.org/10.1166/asem.2014.1538

[43] Kumar, S., Bhanjana, G., Sharma, A., Sidhu, M.C. and Dilbaghi, N. (2014) Synthesis, Characterization and on Field Evaluation of Pesticide Loaded Sodium Alginate Nanoparticles. Carbohydrate Polymers, 101, 1061-1067. https://doi.org/10.1016/j.carbpol.2013.10.025

[44] Choudhary, M.I., Shalaby, A.A. and Al-Omran, A.M. (1995) Water Holding Capacity and Evaporation of Calcareous Soils as Affected by Four Synthetic Polymers. Communications in Soil Science and Plant Analysis, 26, 2205-2215. 
https://doi.org/10.1080/00103629509369440

[45] Hayat, R. and Ali, S. (2004) Water Absorption by Synthetic Polymer (Aquasorb) and Its Effect on Soil Properties and Tomato Yield. International Journal of Agriculture and Biology, 6, 998-1002.

[46] Nangare, K.A., Nagrale, M.R., Dhane, S.S. and Singh, H. (2010) Effect of a Soil Moisture Retentive Material on Yield, Quality and Nutrient Accumulation in Cowpea and Water Retention in Soil. 19th World Congress of Soil Science, Soil Solutions for a Changing World, Brisbane, 1-6 August 2010, 30-32.

[47] Ekebafe, L.O., Ogbeifun, D.E. and Okieimen, F.E. (2011) Polymer Applications in Agriculture. Biokemistri, 23, 81-89.

[48] Dehkordi, K. (2016) The Effects of Superabsorbent Polymers on Soils and Plants. Pertanika Journal of Tropical Agricultural Science, 39, 267-298.

[49] Shahid, S.A., Qidwai, A.A., Anwar, F., Ullah, I. and Rashid, U. (2012) Improvement in the Water Retention Characteristics of Sandy Loam Soil Using a Newly Synthesized Poly (Acrylamide-co-Acrylic Acid)/AlZnFe ${ }_{2} \mathrm{O}_{4}$ Superabsorbent Hydrogel Nanocomposite Material. Molecules, 17, 9397-9412.

https://doi.org/10.3390/molecules 17089397

[50] Ezzo, M.I., Glala, A.A., Habib, H.A.M. and Helaly, A.A. (2010) Response of Sweet Pepper Grown in Sandy and Clay Soil Lysimeters to Water Regimes. AmericanEurasian Journal of Agricultural and Environmental Science, 8, 18-26.

[51] Orikiriza, L.J.B., Agaba, H., Tweheyo, M., Eilu, G., Kabasa, J.D. and Hüttermann, A. (2009) Amending Soils with Hydrogels Increases the Biomass of Nine Tree Species under Non-Water Stress Conditions. Clean-Soil, Air, Water, 37, 615-620. https://doi.org/10.1002/clen.200900128

[52] Ghasemi, M. and Khushkhui, M. (2008) Effects of Super Absorbent Polymer on Irrigation Interval and Growth and Development of Chrysanthemum (Dendranthema grandiflorum Kitam). Iranian Journal of Science and Technology, 8, 65-82.

[53] Akça, Y. and Samsunlu, A. (2012) The Effect of Salt Stress on Growth, Chlorophyll Content, Praline and Nutrient Accumulation and $\mathrm{K} / \mathrm{Na}$ Ratio in Walnut. Pakistan Journal of Botany, 44, 1513-1520.

[54] Osuagwu, G.G.E., Edeoga, H.O. and Osuagwu, A.N. (2010) The Influence of Water Stress (Drought) on the Mineral and Vitamin Potential of the Leaves Ocimum gratissimum L. Recent Research in Science and Technology, 2, 27-33.

[55] Nazarli, H., Zardashti, M.R., Darvishzadeh, R. and Najafi, S. (2010) The Effect of Water Stress and Polymer on Water Use Efficiency, Yield and several Morphological Traits of Sunflower under Greenhouse Condition. Notulae Scientia Biologicae, 2, 53-58. https://doi.org/10.15835/nsb244823

[56] Tongo, A., Mahdavi, A. and Sayad, E. (2014) Effect of Superabsorbent Polymer Aquasorb on Chlorophyll, Antioxidant Enzymes and Some Growth Characteristics of Acacia Victoriae Seedlings under Drought Stress. Ecopersia, 2, 571-582.

[57] Jamnická, G., Ditmarová, L., Kurjak, D., Kmet', J., Pšidová, E., Macková, M., Gömöry, D. and Střelcová, K. (2013) The Soil Hydrogel Improved Photosynthetic Performance of Beech Seedlings Treated under Drought. Plant, Soil and Environment, 59, 446-451. https://doi.org/10.17221/170/2013-PSE

[58] Izanloo, A., Condon, A.G., Langridge, P., Tester, M. and Schnurbusch, T. (2008) Different Mechanisms of Adaptation to Cyclic Water Stress in Two South Australian Bread Wheat Cultivars. Journal of Experimental Botany, 59, 3327-3346.

https://doi.org/10.1093/jxb/ern199 
[59] Nazarli, H., Faraji, F. and Zardashti, M.R. (2011) Effect of Drought Stress and Polymer on Osmotic Adjustment and Photosynthetic Pigments of Sunflower. Cercetări Agronomice în Moldova, 44, 35-41. https://doi.org/10.2478/v10298-012-0022-9

[60] Zhu, Z.B., Liang, Z.S., Han, R.L. and Wang, X. (2009) Impact of Fertilization on Drought Response in the Medicinal Herb Bupleurum chinense DC.: Growth and Saikosaponin Production. Industrial Crops and Products, 29, 629-633. https://doi.org/10.1016/j.indcrop.2008.08.002

[61] Yang, L., Han, Z.M., Yang, L.M. and Han, M. (2010) Effects of Water Stress on Photosynthesis, Biomass, and Medicinal Material Quality of Tribulus terrestri. Chinese Journal of Applied Ecology, 21, 2523-2528.

[62] Alvarez, S., Marsh, E.L., Schroeder, S.G. and Schachtman, D.P. (2008) Metabolomic and Proteomic Changes in the Xylem Sap of Maize under Drought. Plant, Cell \& Environment, 31, 325-340. https://doi.org/10.1111/j.1365-3040.2007.01770.x

[63] Sultana, S., Shariff, M.A., Hossain, M.A., Khatun, A. and Huque, R. (2016) Efecto of Super Water Absorbent (SWA) Hydrogel on Productivity and Quality of Tomato. Archives of Applied Science Research, 8, 5-9.

[64] Sendur-Kumaran, S. (2016) Effect of Hydrophilic Polymers on Yield and Quality of Tomato. International Journal of Applied and Pure Science and Agriculture, 2, 56-60.

[65] Anthon, G.E., Le Strange, M. and Barrett, D.M. (2011) Changes in pH, Acids, Sugars and Other Quality Parameters during Extended Vine Holding of Ripe Processing Tomatoes. Journal of the Science of Food and Agriculture, 91, 1175-1181. https://doi.org/10.1002/jsfa.4312

[66] Borghesi, E., González-Miret, M.L., Escudero-Gilete, M.L., Malorgio, F., Heredia, F.J. and Meléndez-Martínez, A.J. (2011) Effects of Salinity Stress on Carotenoids, Anthocyanins, and Color of Diverse Tomato Genotypes. Journal of Agricultural and Food Chemistry, 59, 11676-11682. https://doi.org/10.1021/jf2021623

[67] Ezzat, A.E.S., El-Awady, A.A. and Ahmed, H.M.I. (2011) Improving Nitrogen Utilization Efficiency by Potato (Solanum tuberosum L.). Nature and Science, 9, 34-42.

[68] Mahmoud, A.W. and Abdulrasoul, M.A. (2012) Effect of Water Quality and Deficit Irrigation on Tomato Growth, Yield and Water Use Efficiency at Different Developmental Stages. Journal of Agricultural and environmental Sciences Damanhur University, 11, 80-110. 